\title{
Surealisme Dalam Seni Lukis Indonesia
}

Anna Sungkar

anna_sungkar@yahoo.co.id

\begin{abstract}
Abstrak
Surealisme yang berkembang pada tahun 1920an di Eropa, mulai mendapatkan gemanya 40 tahun kemudian di Indonesia. Sejak tahun 1963 mulai didapatkan karyakarya surealistik yang terus muncul sampai sekarang. Studi ini didasarkan pada penelitian sebagian koleksi lukisan Galeri Nasional Indonesia yang ada dalam katalog Handbook of Collections Galeri Nasional Indonesia. Terlihat bahwa konten dari lukisan surealisme terpengaruh oleh situasi politik dari dekade ke dekade.
\end{abstract}

Keywords: Surealisme, Psikoanalisa, Sigmund Freud, Salvador Dali, Orde Lama, Orde Baru, Depolitisasi, Spiritual, Hiperrealisme.

Anna Sungkar adalah seorang kurator, pengamat masalah sosial dan budaya, menyelesaikan studi S-3 di ISI Surakarta.

\section{Pendahuluan}

Paper ini bertemakan tentang nafas surealisme dalam seni lukis Indonesia. Surealisme berkembang di Eropa mulai tahun 1924. Aliran itu didasarkan pada penemuan psikoanalisis yang digagas oleh Sigmud Freud (1856 - 1939). Bahwa menurut Freud di dalam jiwa manusia ada gunung es yang tidak terlihat yang disebut sebagai alam bawah sadar. Kesadaran merupakan puncak gunung es dan hanya sebagian kecil saja dari jiwa manusia, sisanya yang terbesar adalah alam bawah sadar. Mimpi-mimpi kita muncul dari alam bawah sadar yang terlempar keluar dari represi. Perasaan-perasaan yang direpresi membentuk ketidaksadaran. Mereka mencari pemuasan substitutif dalam mimpi-mimpi atau 
dengan menciptakan gejala-gejala neurotis. ${ }^{1}$ Karenanya dari mimpi kita menemukan dunia yang berbeda dengan realitas, dunia yang seringkali kacau dan salah tempat. Namun dunia itu kemudian dieksplorasi oleh para pelukis surealis seperti Salvador Dali (1904 - 1989).

Ketika itu ilmu psikoanalisis tentang mimpi dan halusinasi yang dikembangkan Sigmund Freud, menyarankan penggunaan asosiasi kata dan analisa tentang mimpi sebagai metode penciptaan artistik. Andre Breton memberi nama surealisme terhadap seni yang muncul dari analisis mimpi. Dengan surealisme kita dapat membebaskan diri dari pikiran yang terkontrol, dan bebas dari asumsi-asumsi dan prasangka moral serta estetika. Surealisme meninggalkan kepatuhan kepada realitas dalam penggambaran obyek. ${ }^{2}$

Galeri Nasional Indonesia (Galnas) mempunyai banyak karya-karya yang menyiratkan suatu gambaran surealistis atas keadaan yang dipaparkan dalam lukisan. Karenanya tulisan ini berfokus pada nafas surealisme dalam karyakarya yang dikoleksi Galnas. Ada 19 karya yang dipilih, dengan tahun pembuatan yang bervariasi, antara tahun 1963 sampai tahun 2011. Sudah tentu surealisme yang muncul pada karya-karya yang dipilih berbeda dengan surealisme yang ada di Eropa. Adanya nafas mistisisme, kejawaan dan keindonesiaan menjadikan suatu ciri yang unik atas karya-karya koleksi Galnas tersebut. $^{3}$

Dalam karya-karya surealis, bentuk fisik yang real dan koherensi warna, seringkali dilupakan. Lukisan surealis biasanya enigmatik, merupakan bagian alam bawah sadar, dan menjadi teka-teki, bahkan bagi pelukisnya itu sendiri. ${ }^{4}$

\footnotetext{
${ }^{1}$ Bertens, Kees (1980). Memperkenalkan Psikoanalisa. PT. Gramedia, Jakarta, h. xix.

${ }^{2}$ Read, Herbert (1991). A Concise History of Modern Painting. Thames and Hudson, New York, h. 130-2.

${ }^{3}$ Burhan, M. Agus dkk. (2019). Handbook of Collections Galeri Nasional Indonesia, cetakan kedua, Galeri Nasional Indonesia, Jakarta.

${ }^{4}$ Klingsohr-Leroy, Cathrin (2006). Surrealism. Taschen, Koln, h. 38.
} 
Kiranya yang menonjol dalam surealisme adalah permainan simbol yang diambil dari alam bawah sadar. Dali menggunakan simbol-simbol yang berulang dan kadang-kadang simbol-simbol tersebut dibuat multi tafsir. ${ }^{5}$ Hal yang sama terjadi dalam karya pelukis Indonesia sejak tahun 1960-an. Penggunaan metafor anjing, sapi, hitam dan putih sebagai simbol atas kondisi sosial politik tahun 1960-an, barangkali muncul dari mimpi yang diciptakan oleh alam bawah sadar senimannya.

\section{Data Karya}

Dalam katalog Handbook of Collections Galeri Nasional Indonesia yang disusun Agus Burhan, ada 87 karya lukis dan karya dua dimensi (fotografi dan sketsa), 19 di antaranya bernafaskan surealisme. Jumlah yang cukup besar (22\%), hal ini dapat dibandingkan dengan karya abstrak dalam koleksi tersebut yang berjumlah 25 (29\%). Sisanya adalah karya realis (figuratif dan dekoratif). Adapun 19 karya surealistik tersebut dapat diuraikan pada tabel berikut:

\begin{tabular}{|c|c|c|c|}
\hline No. & Nama Seniman & $\begin{array}{l}\text { Keterangan } \\
\text { Karya }\end{array}$ & Foto Karya \\
\hline 1. & Agus Djaja & $\begin{array}{l}\text { Dunia Anjing } \\
45 \times 70 \mathrm{~cm} \\
1965 \\
\text { oil on canvas }\end{array}$ & 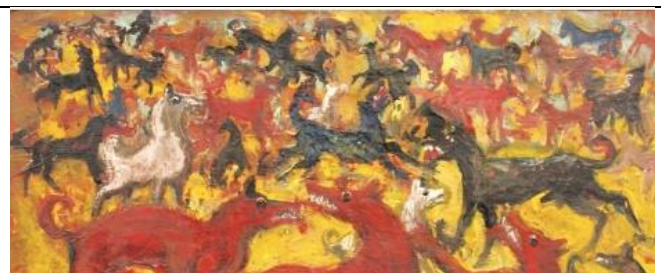 \\
\hline
\end{tabular}

\footnotetext{
${ }^{5}$ Ades, Dawn (1990). Dali. Thames and Hudson, London, h. 85.
} 


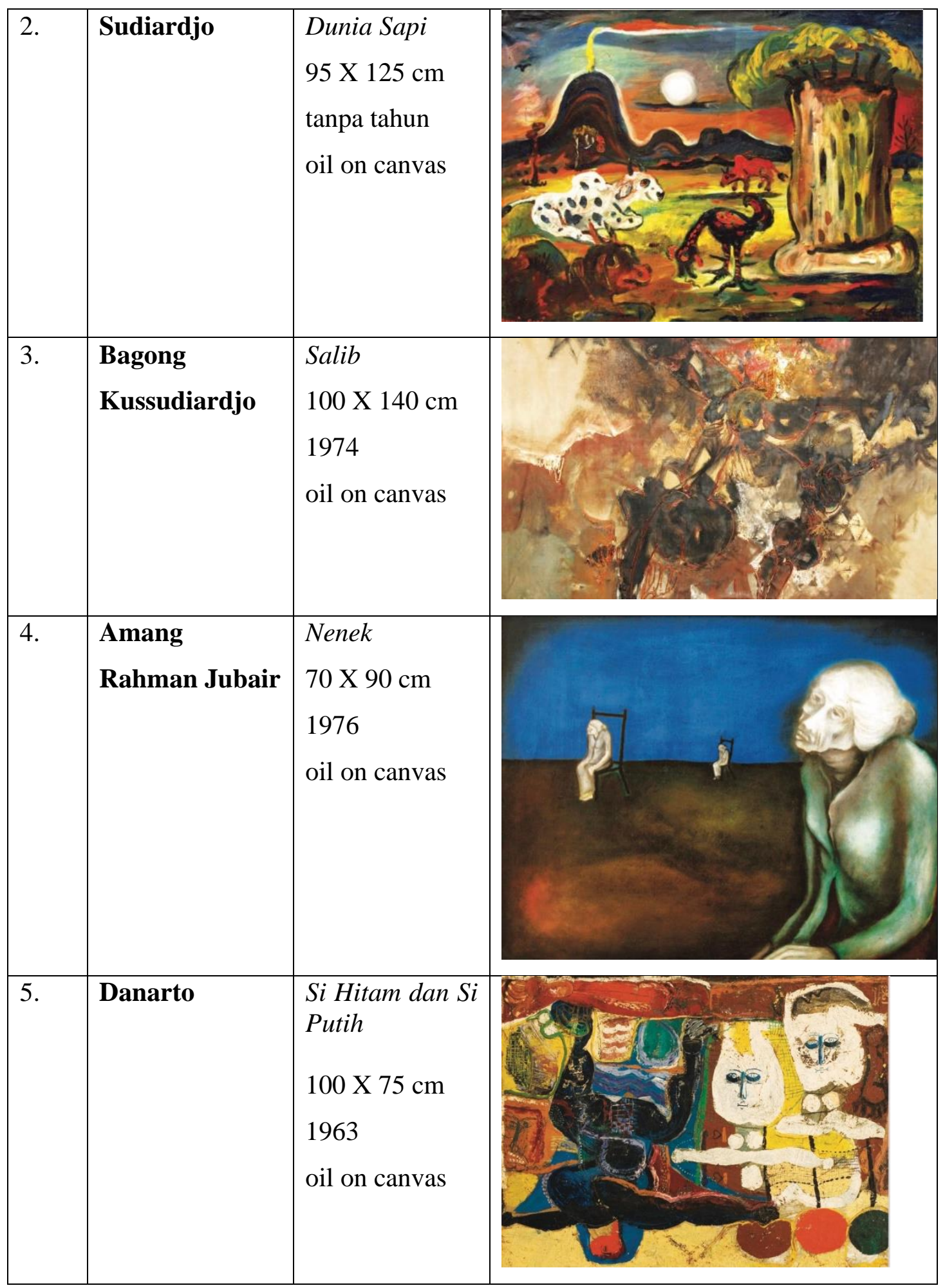




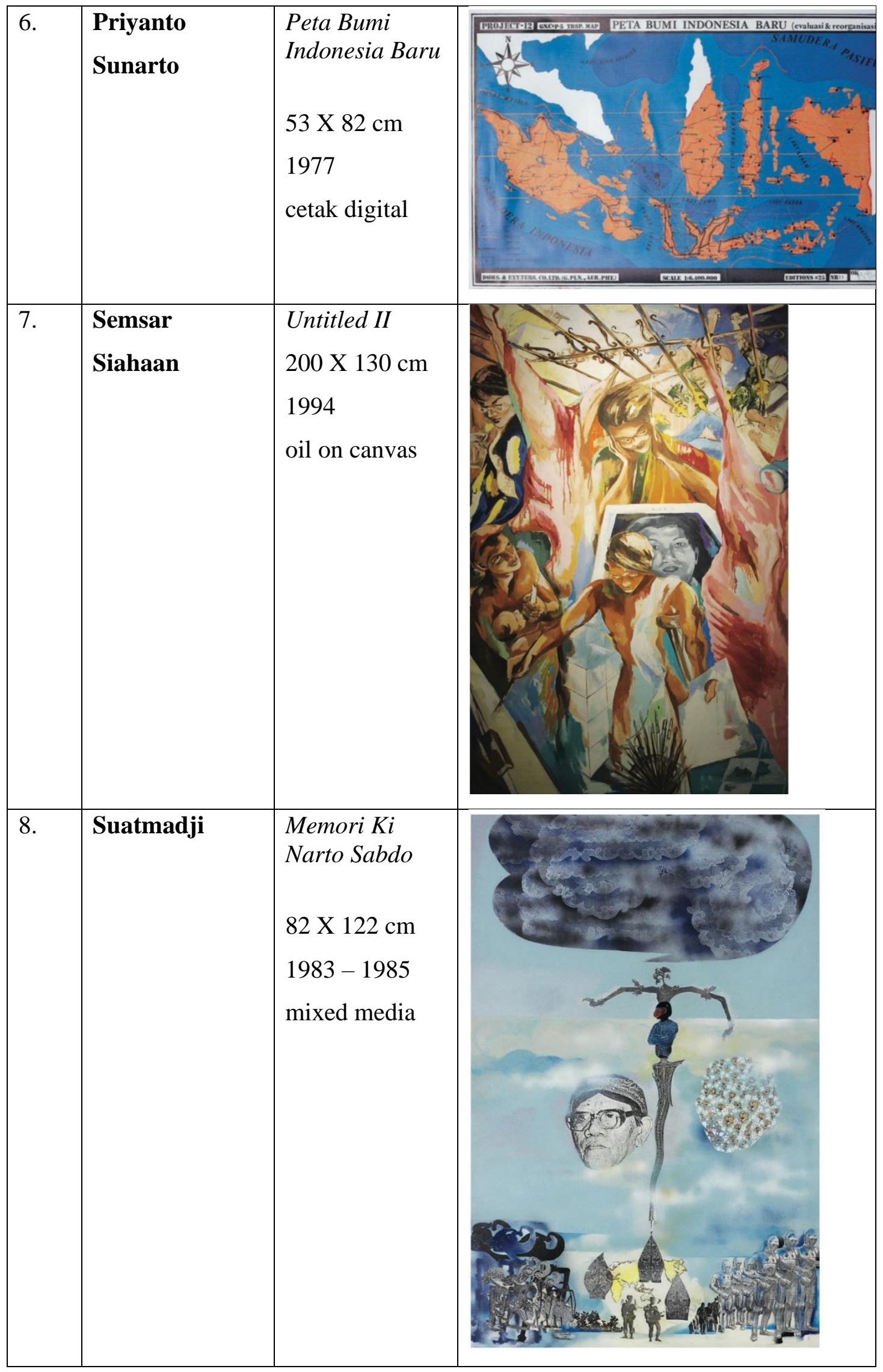




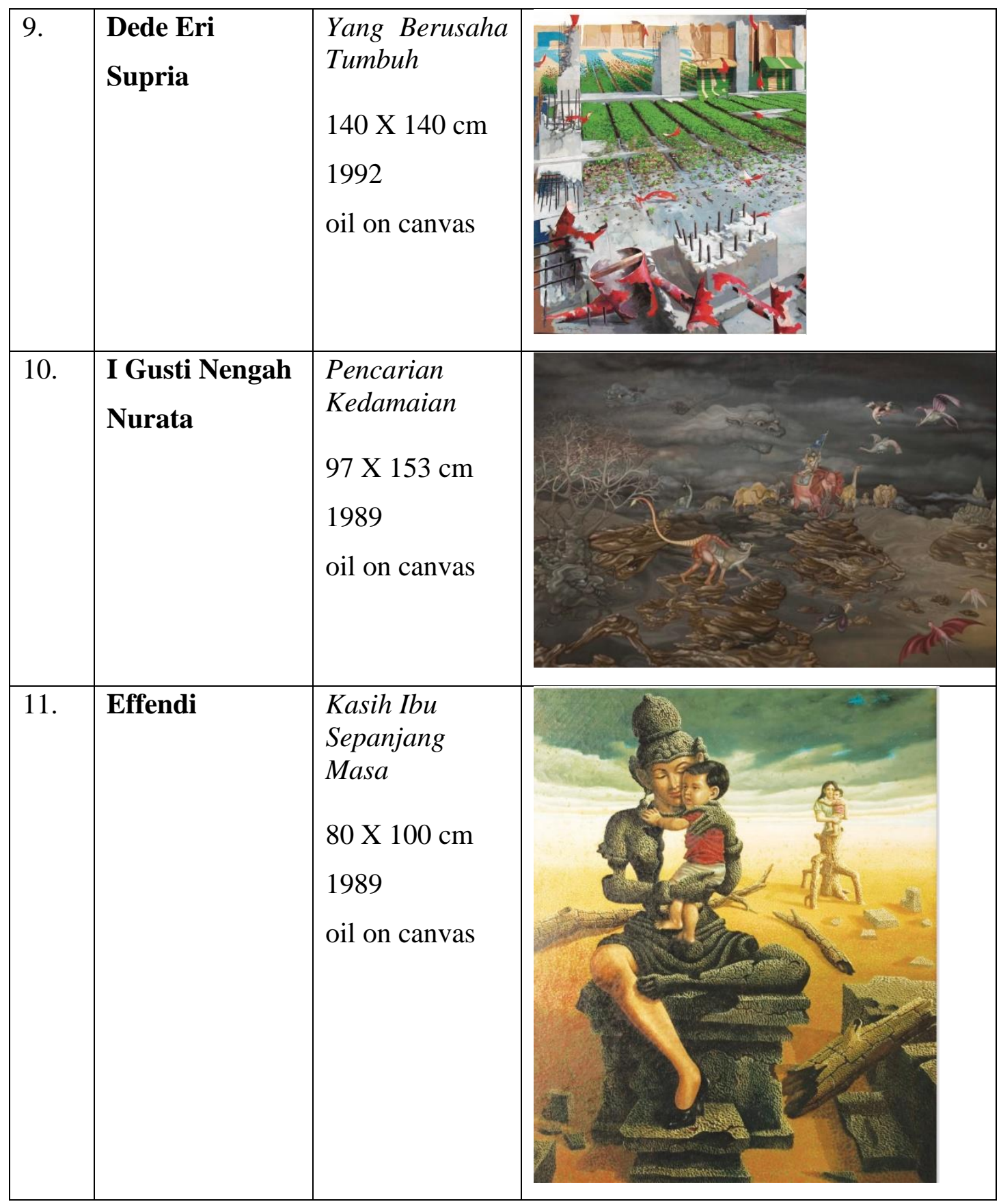




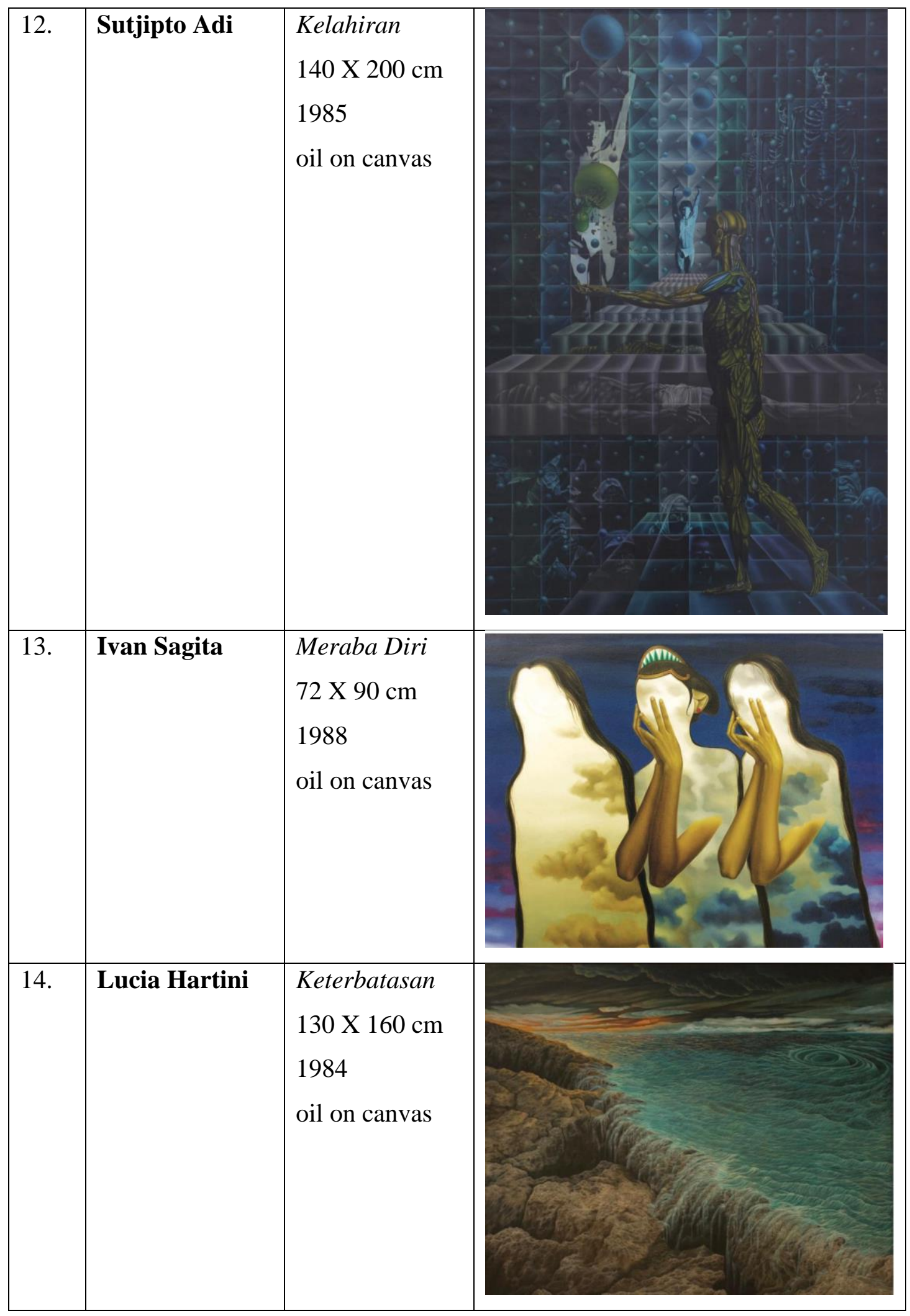




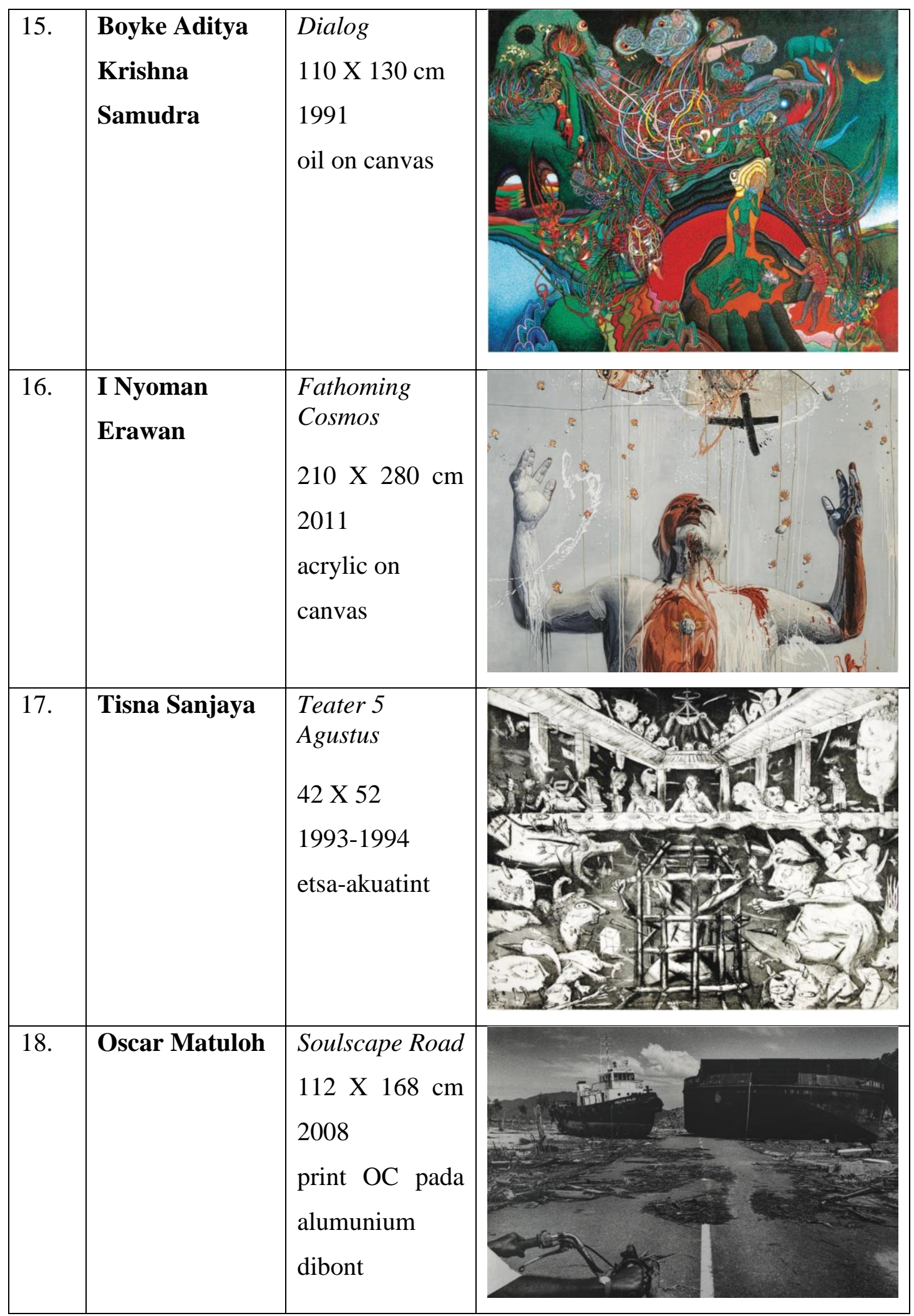




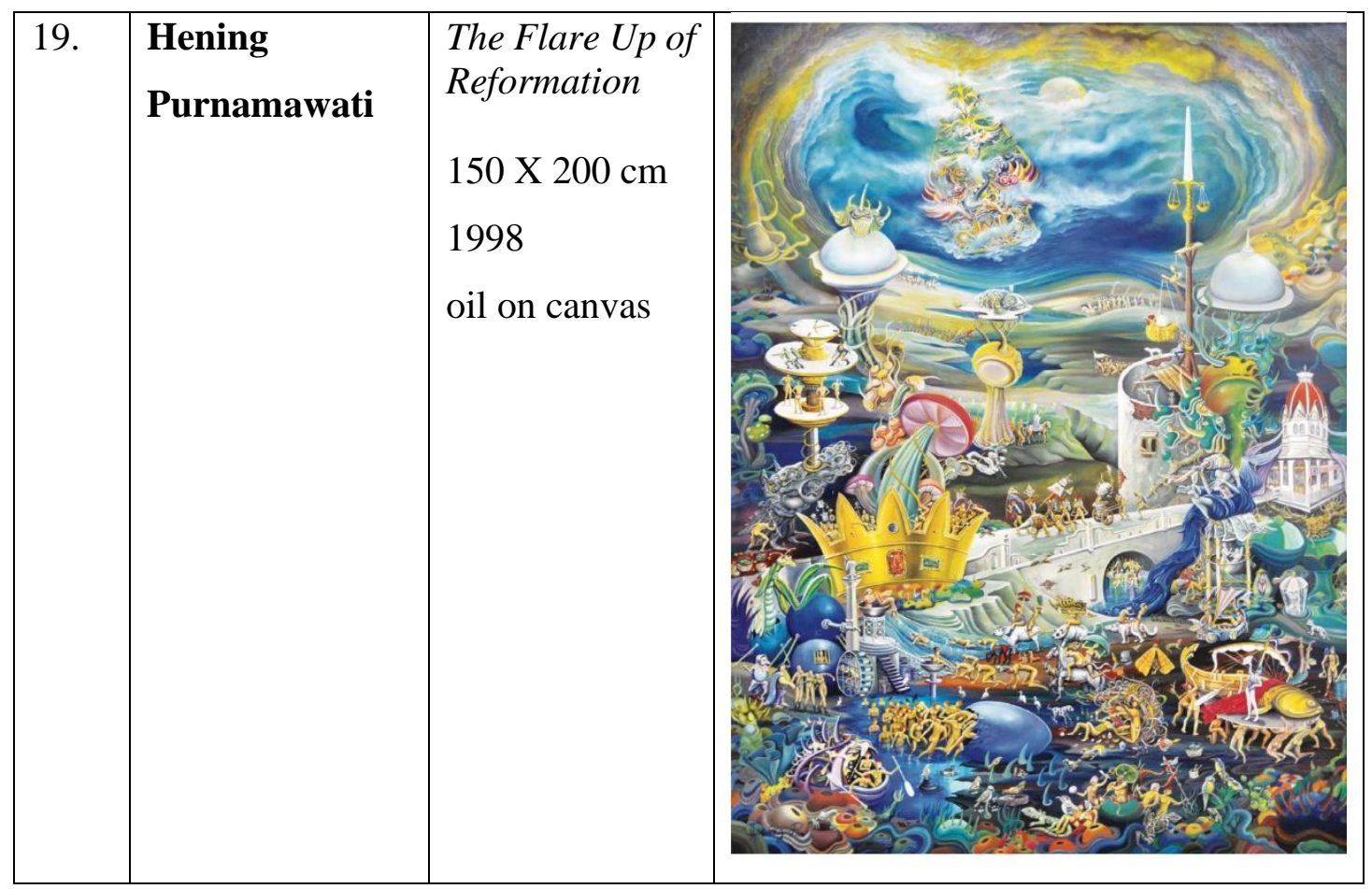

\section{Tahun 1960-an}

Karya-karya yang dipilih akan mencerminkan perkembangan surealisme dalam setiap dekade. Karya seperti "Dunia Anjing” yang dibuat Agus Djaja tahun 1965, dan karya “Si Hitam dan Si Putih" yang dibuat Danarto pada tahun 1963, merepresentasikan situasi politik yang terjadi di tahun 1960-an. Namun karena tekanan dari kaum kiri yang sedang jaya ketika itu, menyebabkan seniman tidak menuangkannya secara gamblang dalam lukisan. Situasi dibuat surealistis, di mana sekumpulan anjing yang banyak sekali sedang berkelahi satu sama lain. Hal yang sebenarnya tidak ada di dunia nyata. Pemilihan warna merah juga menyimbolkan makna tertentu dalam peta kekuasaan ketika itu. Hal yang sama terjadi dengan karya Danarto, ia menggambarkan situasi yang diametral antara si Hitam dengan si Putih yang mencerminkan adanya dua kubu di zaman Orde Lama.

\section{Tahun 1970-an}

Di tahun 1970-an, karya-karya yang surealistik tidak lagi merepresentasikan situasi politik yang hiruk pikuk seperti periode sebelumnya. Para seniman lebih mewujudkan 
suasana kontemplatif dan spiritual, sebagai cerminan atas situasi depolitisasi ketika itu. ${ }^{6}$ Kita dapat melihat pada karya "Salib" (1974) dari Bagong Kussudiardjo, dan "Nenek" (1976) dari Amang Rahman Jubair. Ada juga karya menarik dari Priyanto Sunarto yang melukiskan kepulauan Indonesia dengan posisi yang terbolak-balik dalam karya "Peta Bumi Indonesia Baru" (1977), hal ini dapat dibaca sebagai Indonesia yang sedang berubah wujud di mana ukuran-ukuran yang lama sudah berubah.

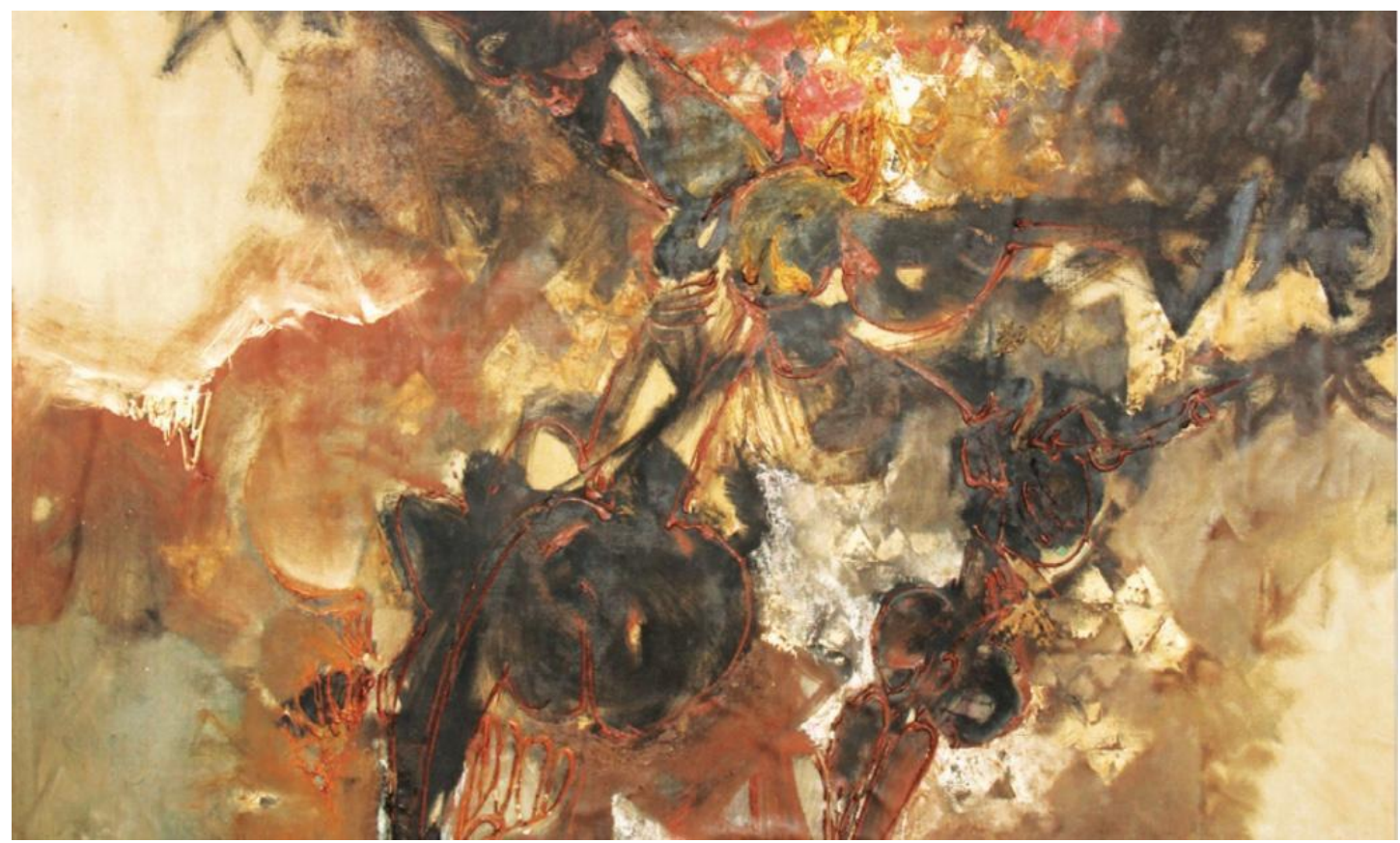

Bagong Kussudiardjo, “Salib”, oil on canvas, 1974.

Bagong Kussudiardjo (1928 - 2004) adalah seorang penari, koreografer dan pelukis. Pada tahun 1945 ia bergabung dengan PTPI (Poesat Tenaga Pelukis Rakyat) yang didirikan oleh Djajengasmoro. Dan setahun kemudian ia bergabung dengan Sanggar Pelukis Rakyat. Karya lukisnya bergaya ekspresionis dengan sapuan kasar dan banyak lelehan dari cat yang basah. Pemilihan warna yang dipakai Bagong cenderung warna yang soft, kombinasi antara kuning oker, orange, hijau dan hitam. Dalam karya-karya Bagong, kita tidak melihat struktur anatomi yang "benar" karena semua figur-figurnya terdistorsi. Demikian pula pada bagian wajah, Bagong biasanya memberikan wajah

\footnotetext{
${ }^{6}$ Jenkins, David (1984). Suharto and His Generals, Indonesian Military Politics 1975-1983. Equinox Publishing, Singapore, h. 80 .
} 
yang kosong saja. Mungkin hal itu disebabkan oleh skill melukisnya yang tidak memadai seperti keahlian merias figur dan wajah ala Basoeki Abdullah, misalnya.

Namun dari kekurangannya itu kita dapat menikmati impresi yang muncul dari balik obyek yang ingin disampaikannya. Pada lukisan "Salib", kita melihat figur Yesus yang tidak indah, namun ia terdistorsi dan tersembunyi dibalik bercak warna coklat-orange yang diciptakannya. Hal yang menonjol dari lukisan adalah tangan dan torso Yesus yang dibuat dengan goresan hitam yang tegas, sehingga Yesus itu nampak seperti kelelawar. Posisi Yesus yang miring telah menciptakan suasana yang surealistis. Dan pemilihan gestur seperti itu telah mendukung dalam pencapaian efek spiritual di dalam lukisan.

Dalam melihat karya "Salib" ini melalui analisis visual, kita dapat menemukan karakteristik Bagong Kussudiardjo sebagai pembuatnya, dengan beberapa ciri seperti munculnya tema spriritual Kristus, sesuai dengan agama yang dianut Bagong. Dengan teknik distorsi dalam menggambar obyek, sebagaimana karya-kaya Bagong umumnya, figur-figur hanya digambarkan sebagai biting hitam tanpa akurasi anatomi. Karya ini juga memperlihatkan adanya teknik ciprat dan lelehan sehingga gayanya terlihat ekspresionis.

\section{Tahun 1980-an}

Tahun 1980-an, para seniman memasuki bentuk baru yaitu mendalami cara melukis akurat dengan warna-warna yang kontras dan bergaya hiperrealisme. Pengaruh Salvador Dali sangat terasa pada karya Suatmadji, "Memori Ki Narto Sabdo" (19831985), Effendi, “Kasih Ibu Sepanjang Masa” (1989), Sutjipto Adi, “Kelahiran” (1985), Ivan Sagita, "Meraba Diri” (1988), Lucia Hartini, "Keterbatasan” (1984), dan I Gusti Nengah Nurata, "Pencarian Kedamaian” (1989). Bentuk-bentuk subyek dalam lukisan Dali yang bolong-bolong pada bagian tubuh terlihat pada karya Effendi dan Ivan Sagita. Demikian pula obyek-obyek terpiuh (deformasi) kita dapati pada karya Suatmadji dan Sutjipto Adi. Pada tahun 80-an, tidak terlihat jejak politis dalam karya-karya surealistik ini, hal ini mencerminkan situasi politik yang tidak lagi terfragmentasi. Sehingga 
seniman lebih mencurahkan pada percobaan bentuk-bentuk baru. Dan surealisme menjadi pilihan acuan yang populer ketika itu.

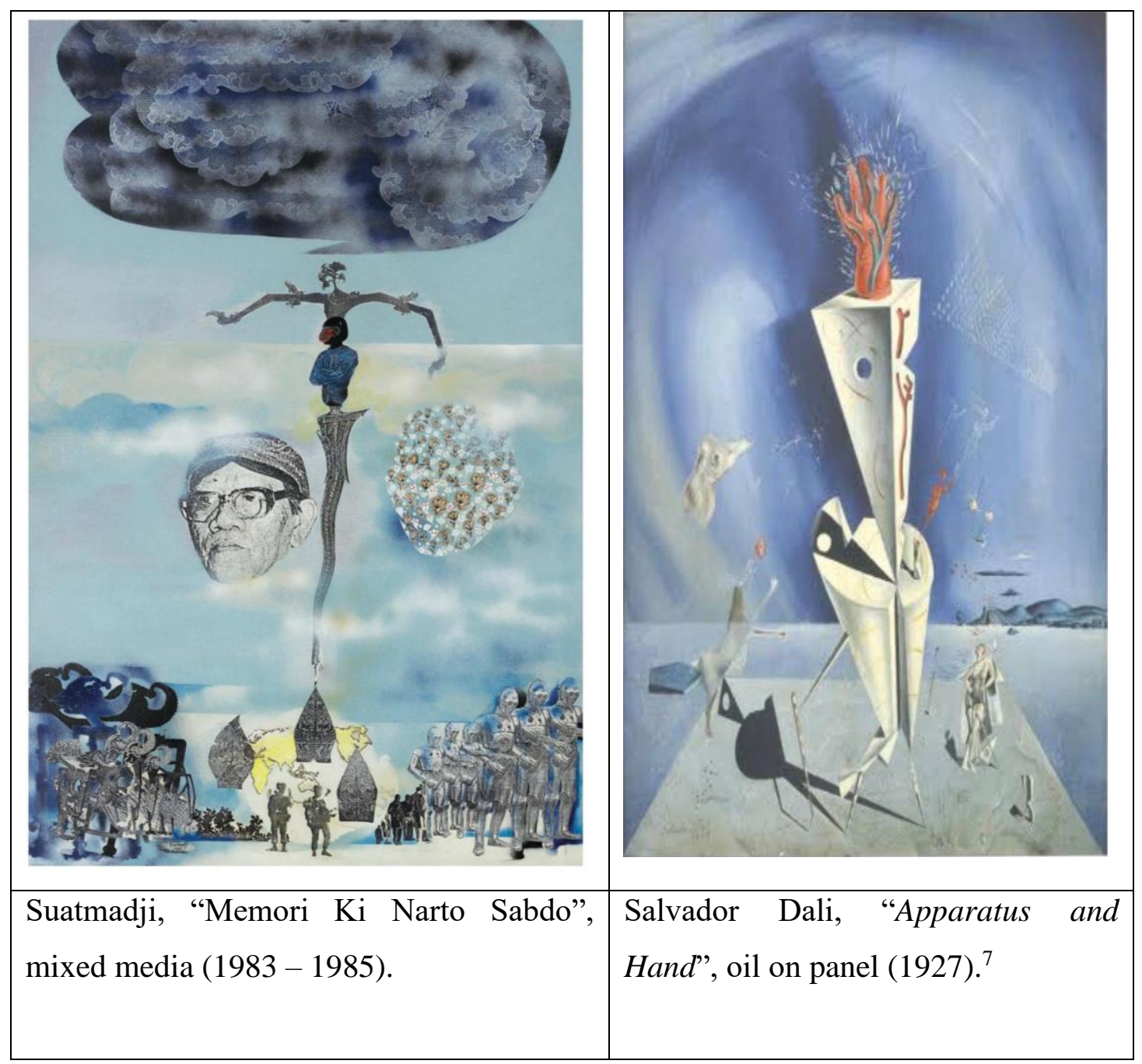

Dapat dibandingkan karya Suatmadji dengan karya Dali yang dibuat tahun 1927. Terlihat adanya pengaruh komposisi, pemilihan warna, dan peletakkan subject figure seperti pada karya “Apparatus and Hand” (1927). Demikian pula dengan karya Effendi, "Kasih Ibu Sepanjang Masa" kita bisa melihat asosiasinya dengan karya Dali, "The Spectre of Sex Appeal" (1932). ${ }^{8}$ Adanya figur anak kecil pada kedua karya tersebut,

\footnotetext{
${ }^{7}$ Dopagne, Jacques (1987). Dali. Spadem, Paris, h. 6.

${ }^{8}$ Dopagne, 62
} 
pemilihan judul dan tema yang memper satu sama lain, makin memperlihatkan adanya pengaruh Dali pada karya Effendi.

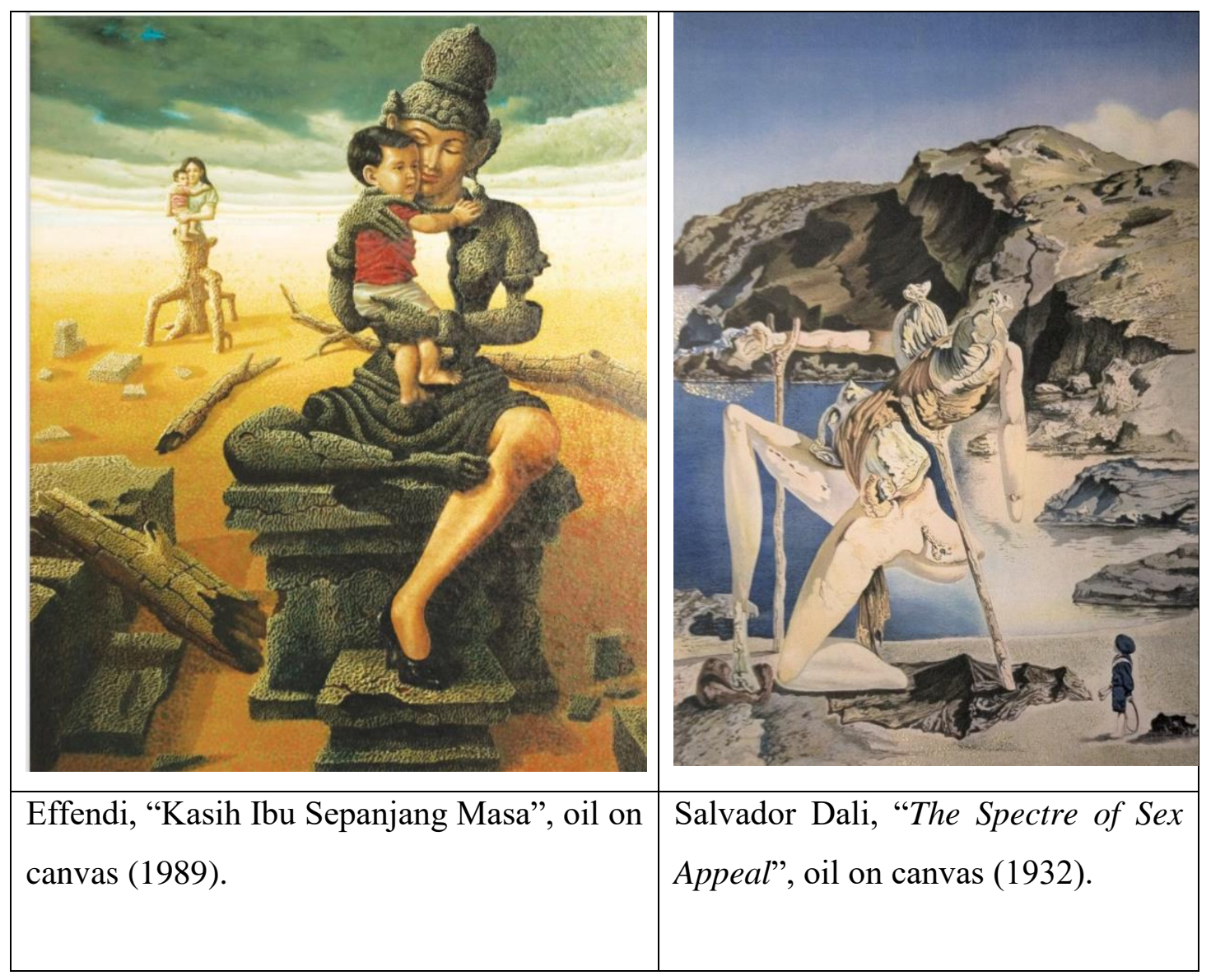

\section{Tahun 1990-an}

Tahun 1990-an, ditandai dengan karya Dede Eri Supria, "Yang Berusaha Tumbuh" (1992), sebuah karya yang merupakan impian seniman atas pembangunan yang terlalu masif ketika itu. Ada kebun terhampar dalam tumpukan beton, merupakan sebuah protes atas pembangunan yang tidak mempedulikan lingkungan. 


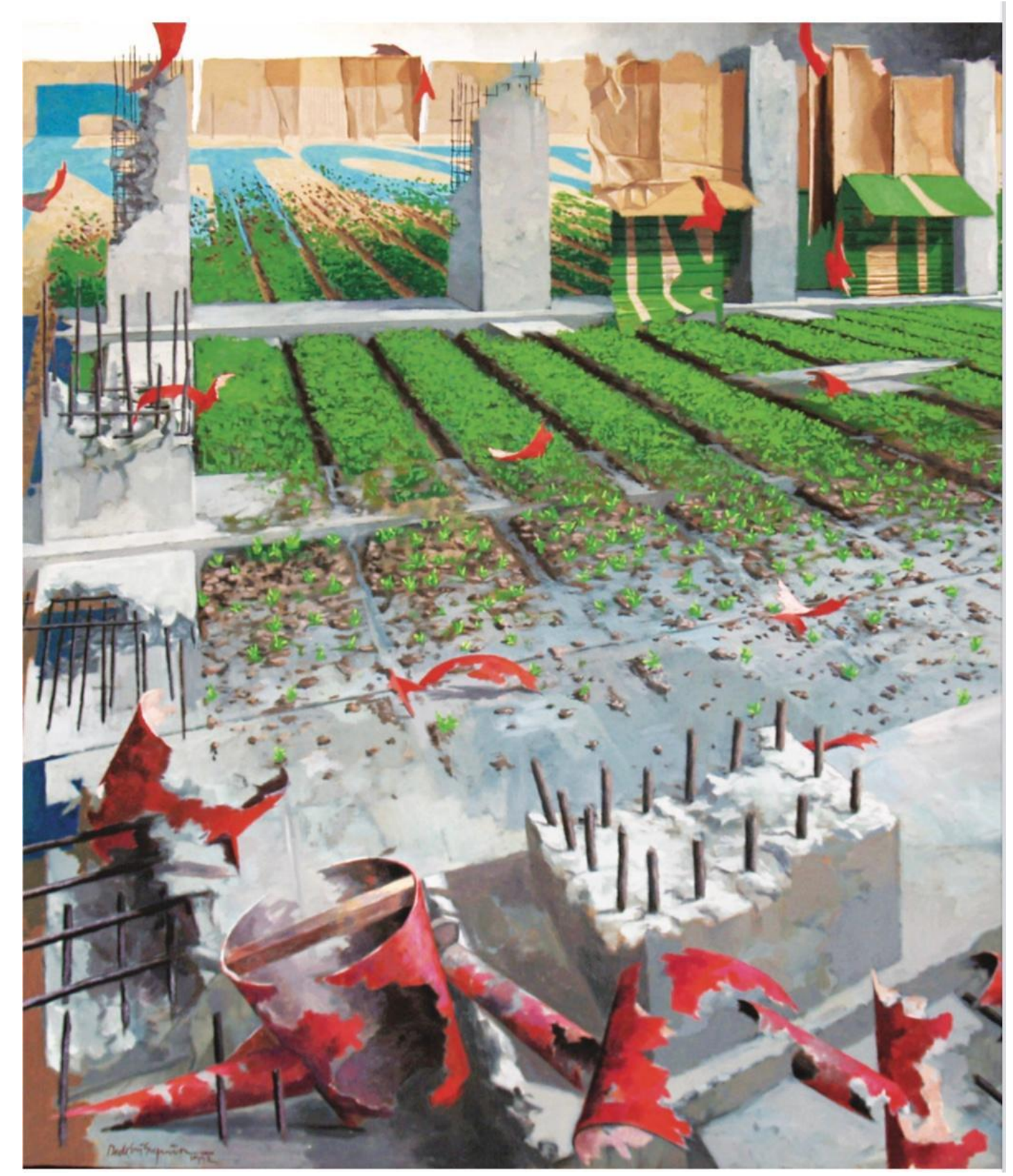

Dede Eri Supria, "Yang Berusaha Tumbuh", oil on canvas, 1992.

Dede Eri Supria (29 Januari 1956 - ) merupakan seorang pelukis beraliran realisme sosial. Di mana pada karya-karyanya ia melakukan kritik sosial terhadap kejadiankejadian yang ada dalam masyarakat. Karir melukisnya dimulai ketika ia terlibat dalam Gerakan Seni Rupa Baru (GSRB) di tahun 1975. Dalam pameran GSRB dipamerkan karyanya yang berjudul "Urbanisasi". Terlihat si pelukis sedang berdiri di emperan rumah di pinggir kali yang kotor, dan pada bagian kanan tampak rumah-rumah darurat yang dibuat dari potongan bambu yang ringkih. Jelas bahwa rumah-rumah tersebut 
menempati sebagian dari badan kali. Kali itu penuh sampah, yang berasal dari rumahrumah darurat tersebut maupun sampah dari tempat lain yang terbawa oleh aliran sungai. Lukisan itu dibuat dengan teknik realisme foto, sehingga kita dapat merasakan bentuk rumah-rumah darurat itu beserta kalinya dengan sangat detail. Adapun maksud dari Dede melukis seperti itu sudah pasti merupakan sindiran kepada pemerintah kota yang tidak mengurusi kehidupan kaum pinggiran di daerah kumuh. Penduduk yang terisisih itu sebetulnya kaum pendatang dari luar Jakarta, yang mencari nafkah di sektor informal.

Karya-karyanya pada tahun 1990-an berkutat pada ketimpangan ekonomi, rakyat kecil, pembangunan yang mengabaikan lingkungan dan ditujukan untuk kepentingan masyarakat golongan atas dari pemerintahan Orde Baru. ${ }^{9}$ Ia banyak mendapat input tentang ketidakadilan sosial ketika ia bekerja di Tempo sebagai pembuat cover majalah. Cara berkaryanya menggunakan teknik photoshop dengan melakukan superimpose atas beberapa obyek. Itulah sebabnya karya-karyanya menjadi sangat akurat di dalam penggambaran obyeknya. Pada karya ini kita melihat superimpose antara tiga obyek, yaitu fondasi beton, robekan karton dan hamparan tanaman. Kita melihat juga pengaruh Richard Estes, seorang pelukis fotorealis Amerika, yang memberikan warna-warna cerah pada karya-karyanya. Beton dan karton merupakan salah satu ciri yang menandakan karya-karya Dede di tahun 1990-an.

Lukisan Hening Purnamawati menjadikan penanda dalam penutupan rezim Orde Baru pada karyanya "The Flare Up of Reformation" (1998). Di bagian tengah lukisan Hening, kita akan melihat sebuah jembatan yang pada ujungnya ada mahkota raksasa berwarna emas, sedangkan ujung jembatan yang lain adalah gambaran sebuah istana. Subject figure yang tersebar dalam lukisan merupakan simbol-simbol yang diserahkan kepada pemirsa untuk memahami maksudnya, yang terasa adalah situasi chaos terjadi pada seluruh bagian lukisan yang merepresentasikan suasana reformasi tahun 1998. Dalam karya itu kita melihat kembali ada nafas Dali dalam karyanya, sesuatu yang

\footnotetext{
${ }^{9}$ Dermawan T., Agus (1999). Dede Eri Supria, Elegi Kota Besar. Yayasan Seni Rupa AiA, Jakarta, h. 60.
} 
menjadi ciri-ciri karya lukis surealis sejak tahun 80 -an. Kita dapat membandingkan karya Dali, "Dionysus Spitting the Complete" (1958) ${ }^{10}$ dengan karya Hening ini.

\section{Tahun 2000-an}

Tahun 2000-an, ditandai dengan karya foto Oscar Matullah yang nampaknya sedang bermain-main dalam mengenang peristiwa Tsunami Aceh. Kita melihat ada kapal yang berdiri di jalan raya dalam karya "Soulscape Road" (2008). Suatu situasi yang real namun terasa surealistik. Demikian pula pada karya Nyoman Erawan, "Fathoming Cosmos" (2011), manusia yang digambarkan Erawan dengan suasana yang mengelilinginya, terasa surealistik.

\section{Kesimpulan}

Kita melihat bentuk-bentuk surealistik dalam karya lukis Indonesia berlangsung dari dekade ke dekade. Di setiap dekade selalu ada seniman-seniman yang menggunakan surealisme sebagai bentuk pengucapan yang cocok dengan pemikiran yang mereka ingin ungkapkan. Konten dari karya-karya di setiap dekade berubah-ubah sesuai dengan situasi pada zamannya. Pada tahun 60-an terlihat adanya situasi yang diametral dalam politik kebudayaan Indonesia dengan memperlihatkan adanya yang kiri dan yang kanan. Namun di tahun 70 -an situasinya berubah, pesan politik dihindari. Tahun 80 -an surealisme demikian trend sehingga kita banyak melihat karya-karya yang bernafaskan Salvador Dali. Selanjutnya di tahun 90 -an sudah mulai muncul protes pada karya-karya dalam dekade itu. Hal itu disebabkan masifnya pembangunan yang banyak mengorbankan rakyat kecil. Tahun 2000-an setelah mengalami reformasi dan keterbukaan politik, seniman lebih banyak melakukan eksperimentasi untuk menciptakan karya-karya surealistik. Nampak pengaruh teknologi dan efek bermainmain dalam karya Oscar Matullah dan Nyoman Erawan. Tidak terlihat jejak pesan politik pada karya mereka, barangkali karena tidak ada lagi rezim yang perlu ditumbangkan di zaman yang demokratis ini.

\footnotetext{
${ }^{10}$ Dopagne, 82
} 


\section{Referensi}

1. Ades, Dawn (1990). Dali. Thames and Hudson, London.

2. Dermawan T., Agus (1999). Dede Eri Supria, Elegi Kota Besar. Yayasan Seni Rupa AiA, Jakarta.

3. Dopagne, Jacques (1987). Dali. Spadem, Paris.

4. Jenkins, David (1984). Suharto and His Generals, Indonesian Military Politics 1975-1983. Equinox Publishing, Singapore.

5. Klingsohr-Leroy, Cathrin (2006). Surrealism. Taschen, Koln.

6. Read, Herbert (1991). A Concise History of Modern Painting. Thames and Hudson, New York. 